UK Monetary Policy from Devaluation to Thatcher, 1967-82 
Palgrave Studies in the History of Finance

Series Editors: Adrian R. Bell, D’Maris Coffman, and Tony K. Moore

The study of the history of financial institutions, markets, instruments, and concepts is vital if we are to understand the role played by finance today. At the same time, the methodologies developed by finance academics can provide a new perspective for historical studies. Palgrave Studies in the History of Finance is a multi-disciplinary effort to emphasise the role played by finance in the past, and what lessons historical experiences have for us. It presents original research, in both authored monographs and edited collections, from historians, finance academics and economists, as well as financial practitioners.

Titles include:

D'Maris Coffman

EXCISE TAXATION AND THE ORIGINS OF PUBLIC DEBT

Duncan Needham

UK MONETARY POLICY FROM DEVALUATION TO THATCHER, 1967-82

Palgrave Studies in the History of Finance series

Series Standing Order ISBN: 978-1-137-34224-9

(outside North America only)

You can receive future titles in this series as they are published by placing a standing order. Please contact your bookseller or, in case of difficulty, write to us at the address below with your name and address, the title of the series and the ISBN quoted above.

Customer Services Department, Macmillan Distribution Ltd, Houndmills, Basingstoke, Hampshire RG21 6XS, England 


\section{UK Monetary Policy from Devaluation to Thatcher, 1967-82}

Duncan Needham

Darwin College, University of Cambridge 


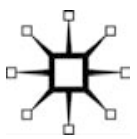

(C) Duncan Needham 2014

Softcover reprint of the hardcover 1st edition 2014 978-1-137-36953-6

All rights reserved. No reproduction, copy or transmission of this publication may be made without written permission.

No portion of this publication may be reproduced, copied or transmitted save with written permission or in accordance with the provisions of the Copyright, Designs and Patents Act 1988, or under the terms of any licence permitting limited copying issued by the Copyright Licensing Agency, Saffron House, 6-10 Kirby Street, London EC1N 8TS.

Any person who does any unauthorized act in relation to this publication may be liable to criminal prosecution and civil claims for damages.

The author has asserted his right to be identified as the author of this work in accordance with the Copyright, Designs and Patents Act 1988.

First published 2014 by

PALGRAVE MACMILLAN

Palgrave Macmillan in the UK is an imprint of Macmillan Publishers Limited, registered in England, company number 785998, of Houndmills, Basingstoke, Hampshire RG21 6XS.

Palgrave Macmillan in the US is a division of St Martin's Press LLC, 175 Fifth Avenue, New York, NY 10010.

Palgrave Macmillan is the global academic imprint of the above companies and has companies and representatives throughout the world.

Palgrave ${ }^{\circledR}$ and Macmillan ${ }^{\circledR}$ are registered trademarks in the United States, the United Kingdom, Europe and other countries

ISBN 978-1-349-47499-8

ISBN 978-1-137-36954-3 (eBook)

DOI $10.1057 / 9781137369543$

This book is printed on paper suitable for recycling and made from fully managed and sustained forest sources. Logging, pulping and manufacturing processes are expected to conform to the environmental regulations of the country of origin.

A catalogue record for this book is available from the British Library.

A catalog record for this book is available from the Library of Congress. 
To my parents 
This page intentionally left blank 


\section{Contents}

List of Illustrations viii

Preface ix

Note on Chronology $\quad \mathrm{x}$

Definitions of UK Monetary Aggregates xi

Acknowledgments xii

List of Abbreviations $\quad$ xiii

$\begin{array}{lr}\text { Introduction } & 1\end{array}$

1 From Devaluation to Competition and Credit Control, $\begin{array}{ll}\text { 1967-71 } & 21\end{array}$

2 Competition and Credit Control, 1971-73 46

3 The PSBR Takes Over, 1974-76 78

4 Too Many Targets, 1977-79 109

5 The Lady Is for Turning, 1979-82 134

$\begin{array}{lr}\text { Conclusion } & 169\end{array}$

$\begin{array}{ll}\text { List of Names } & 175\end{array}$

$\begin{array}{lr}\text { Chronology of Events } & 179\end{array}$

$\begin{array}{ll}\text { Notes } & 185\end{array}$

Bibliography of Cited Secondary Sources 240

$\begin{array}{lr}\text { Index } & 247\end{array}$ 


\section{List of Illustrations}

\section{Figures}

2.1 Net sales of public-sector debt to the non-bank public, 1972-73

4.1 The sterling exchange rate, 1977-79

4.2 Changes in real household income, 1967-82

\section{Tables}

I.1 Bank of England 'ladder of recognitions' in 1967

I.2 The clearing banks' cartel lending rates in $1968 \quad 15$

2.1 Lending by sector to UK residents, May 1971 to August 1973

2.2 Initial supplementary special deposit penalty thresholds, December 1973

5.1 Original MTFS targets and outturns 


\section{Preface}

This book charts the course of monetary policy in the UK from the 1960s to the early 1980s. It shows how events such as the 1967 sterling devaluation, the collapse of Bretton Woods, the stagflation of the 1970s, and the International Monetary Fund (IMF) loan of 1976 all shaped policy. It challenges the existing historiography by showing the Bank of England and the UK Treasury experimenting with money supply targets nearly a decade before the Thatcher government placed monetarism at the heart of economic policy. The catalyst was provided by the IMF after devaluation in 1967. The result, in 1971, was Competition and Credit Control - the most radical overhaul of UK monetary policy since the Second World War.

This early experiment in monetary targeting was not a success. Despite having unpublished monetary targets in place, 1972-73 saw unprecedented growth in the UK money supply. Two years later, inflation hit record levels, apparently vindicating Milton Friedman's claim that excess monetary growth leads inexorably to higher prices after a long and variable lag. The experience reminded senior Bank and Treasury officials that it is impracticable to exercise tight control over the UK money supply. Paradoxically, it also persuaded influential politicians, academics, and commentators, less aware of the technical difficulties and realities of monetary policy implementation, that only tighter control of the money supply would cure Britain of her inflationary ills. The result was the Medium-Term Financial Strategy (MTFS), launched by the Thatcher government in March 1980.

The MTFS was based on a fundamental misreading of 1970s monetary policy. It produced a recession of unnecessary depth and severity that required the monetary policy U-turn of the 1981 Budget, the most controversial in postwar British history. Fiscal policy was tightened - to the bewilderment of much of the economics profession; monetary policy was loosened - to the relief of British business. This rebalancing allowed personal consumption, through increased household debt, to become the engine of growth in the 1980s. This failure to heed the lessons of 1970s monetary policy, and the subsequent increase in personal debt, has had profound long-term consequences for the shape of the British economy. 


\section{Note on Chronology}

In this book, '1972/73' means the fiscal year ending April 1973. '1972-73' means the two calendar years 1972 and 1973. This sometimes differs in quotations from primary sources. 


\section{Definitions of UK Monetary Aggregates}

M0 Monetary liabilities of the Bank of England, coin issued by the Royal Mint, and the fiduciary note issue of the Scottish and Northern Irish banks.

M1 Currency in circulation with the public and UK residents' sterling sight deposits with UK banks.

M3 Currency in circulation with the public (excluding cash in banks' vaults but including non-UK residents' currency holdings) and the (sterling and foreign currency) deposits (including time deposits and certificates of deposit) of UK (public and private) residents with UK banks.

$£$ M3 Currency in circulation with the public and the sterling deposits of UK residents with UK banks. 


\section{Acknowledgements}

This book is dedicated to the members of the Bank of England's Money Supply Group, who believed in 1969 that the UK money supply was controllable, and the members of the Treasury Historical Section who, if they had still been around in 1979, might have told Conservative ministers that it was not.

I should like to thank all those who provided advice, assistance, and encouragement during the writing of this book. I am grateful to the late Lord Croham, Sir Samuel Brittan, Sir Alan Budd, Sir Douglas Wass, William Allen, Martin Chick, D'Maris Coffman, Charles Goodhart, Anthony Hotson, Peter Jay, William Keegan, Adrian Leonard, Ted Needham, Owen Sanderson, and Jim Tomlinson, who all ploughed through earlier versions of individual chapters without, of course, necessarily agreeing with the arguments therein. All errors remain mine alone.

The members of the Financial History Seminar, the Economic and Social History Seminar and the Contemporary History Workshop in Cambridge, the Monetary History Seminar in London, the Winton Seminar on Monetary History in Oxford, and the Economic History Society Conference in York all provided valuable comments on presentations.

Thanks also to Mike Anson, Sarah Millard, and Ben White at the Bank of England Archive, Jeremy McIlwaine at the Conservative Party Archive in Oxford, the staff of the National Archives at Kew, Premela Isaac at the IMF Archive in Washington, and the many staff of the various Cambridge University libraries who gracefully put up with requests for books, journals, microfiches, newspapers, and pamphlets that just could not wait.

Special thanks go to my PhD supervisor Martin Daunton for always asking the difficult questions. 


\section{List of Abbreviations}

$\begin{array}{ll}\text { BEQB } & \text { Bank of England Quarterly Bulletin } \\ \text { BOE } & \text { Bank of England Archive } \\ \text { CBI } & \text { Confederation of British Industry } \\ \text { CCC } & \text { Competition and Credit Control } \\ \text { CPA } & \text { Conservative Party Archive } \\ \text { CPRS } & \text { Central Policy Review Staff } \\ \text { CRD } & \text { Conservative Research Department } \\ \text { DCE } & \text { Domestic Credit Expansion } \\ \text { EBM } & \text { Executive Board Minutes (IMF) } \\ \text { EEC } & \text { European Economic Community } \\ \text { ERG } & \text { Economic Reconstruction Group } \\ \text { ERI } & \text { Exchange Rate Index } \\ \text { ERM } & \text { Exchange Rate Mechanism } \\ \text { FT } & \text { Financial Times } \\ \text { GDP } & \text { Gross Domestic Product } \\ \text { HMG } & \text { Her Majesty's Government } \\ \text { HMT } & \text { Her Majesty's Treasury } \\ \text { IBEL } & \text { Interest-Bearing Eligible Liabilities } \\ \text { IMF } & \text { International Monetary Fund } \\ \text { LBS } & \text { London Business School } \\ \text { LSE } & \text { London School of Economics } \\ \text { MBC } & \text { monetary base control } \\ \text { MLR } & \text { Minimum Lending Rate } \\ \text { MPG } & \text { Monetary Policy Group comprising Bank and Treasury officials } \\ \text { MTFS } & \text { Medium-Term Financial Strategy } \\ \text { NAIRU } & \text { Non-Accelerating Inflation Rate of Unemployment } \\ \text { NEDC } & \text { National Economic Development Council } \\ \text { NEDO } & \text { National Economic Development Office } \\ \text { OPEC } & \text { Organization of the Petroleum Exporting Countries } \\ \text { PCC } & \text { Policy Co-ordinating Committee, HM Treasury } \\ \text { PSBR } & \text { Public Sector Borrowing Requirement } \\ \text { SDR } & \text { Special Drawing Rights } \\ \text { TNA } & \text { The National Archives } \\ \text { TUC } & \text { Trades Union Congress } \\ & \end{array}$

